Revista Bioética

\title{
ATUALIZAÇÃO
}

\section{Medicine, torture, the death penalty and the democratic state: from collaboration to emancipation}

Dirceu Greco ${ }^{1}$, James Welsh ${ }^{2}$

1. Universidade Federal de Minas Gerais, Belo Horizonte/MG, Brasil. 2. University of London, London, United Kingdom.

\begin{abstract}
Abuses of medicine have taken place over past decades in the context of torture and the death penalty. Serious and totally unacceptable breaches of medical ethics and human rights have occurred in institutions caring for vulnerable people. And yet there is still a need to make visible the whole spectrum of violence and breaches of human rights and to challenge them. This paper discusses a wide range of abuses in which medical professionals may take part whether as witnesses, bystanders or participants. It also addresses changes that are needed to benefit citizens at risk of abuse and to strengthen the ethical practice of medicine. The frequently-used term "empowerment" as applied to populations at risk signals a step in the right direction but usually involves the top-down giving of limited power to people. What oppressed people need is to claim their human rights - to emancipate themselves.
\end{abstract}

Keywords: Bioethics. Ethics. Human rights. Torture. Capital punishment.

\section{Resumo}

Medicina, tortura, pena de morte e o estado democrático: da colaboração à emancipação

Abusos médicos têm ocorrido nas últimas décadas no contexto da tortura e da pena de morte. Violações graves e totalmente inaceitáveis de ética médica e dos direitos humanos ocorreram em instituições que cuidam de pessoas vulneráveis. $\mathrm{E}$, no entanto, ainda há uma necessidade de tornar visível todo o espectro de violência e violações dos direitos humanos e desafiá-los. Este artigo discute uma ampla gama de abusos que os profissionais médicos podem enfrentar, seja como testemunhas, espectadores ou participantes. Também são abordadas as mudanças necessárias para beneficiar os cidadãos em risco de abuso e fortalecer a prática ética da medicina. 0 termo "empoderamento", frequentemente aplicado a populações em risco, sinaliza um passo na direção certa, mas normalmente envolve a concessão limitada de poder às pessoas, "de cima para baixo". O que as pessoas oprimidas precisam é reivindicar seus direitos humanos - emancipar a si mesmas.

Palavras-chave: Bioética. Ética. Direitos humanos. Tortura. Pena de morte.

\section{Resumen}

\section{Medicina, tortura, pena de muerte y estado democrático: de la colaboración a la emancipación}

Los abusos de la medicina han tenido lugar en las últimas décadas en el contexto de la tortura y la pena de muerte. Faltas graves y totalmente inaceptables a la ética médica y a los derechos humanos se han producido en instituciones que atienden a personas vulnerables. $\mathrm{E}$, incluso, existe además la necesidad de hacer visible todo el espectro de violencias y de violaciones a los derechos humanos que los ponen en entredicho. Este artículo analiza una amplia gama de abusos que los profesionales médicos pueden enfrentar ya sea como testigos, espectadores o participantes. También se ocupa de los cambios que son necesarios para beneficiar a los ciudadanos en riesgo de abuso y para fortalecer la práctica ética de la medicina. El frecuentemente utilizado término "empoderamiento", aplicado a las poblaciones en riesgo señala un paso en la dirección correcta, pero por lo general implica un movimiento de arriba hacia abajo, otorgando un poder limitado a las personas. Lo que las personas oprimidas necesitan es reivindicar sus derechos humanos para emanciparse.

Palabras clave: Bioética. Ética. Derechos humanos. Tortura. Pena de muerte. 
The struggle for the triumph of ethics and human rights was dominated by the 12 years of Nazi rule in Germany and occupied territories in the $20^{\text {th }}$ century ${ }^{1}$. The ethics vision that emerged reflected the gravity of the abuses of the period. But decades after the end of Nazism, other abuses were documented and led to considerable reflection about the role of doctors where professional practice took place in an abusive environment. In this manuscript we review this experience and suggest some of the action needed to address such abuses.

\section{Doctors and torture}

The military dictatorships in many Latin American countries in the 1960s and 1970s were accompanied by widespread use of torture and extrajudicial killings of opponents. In addition, there were allegations of systematic involvement of doctors in torture in Argentina, Brazil, Chile and Uruguay ${ }^{2-5}$. Doctors were alleged to have resuscitated detainees following collapse during torture, to have advised interrogators on torture methodologies, produced false medical and death certificates and, in general, lent a medical imprimatur to ill-treatment. In Greece, political prisoners were treated by doctors during the military dictatorship from 1967 to 1974 and one of those doctors was brought to trial and imprisoned for unethical disregard of the needs of prisoners who had been tortured ${ }^{6}$.

In the former the Union of Soviet Socialist Republics (USSR), some critics and dissidents were subjected to involuntary committal to mental institutions where they were forcibly given unneeded medical treatment ${ }^{7}$. The objective of this detention and "treatment" was not to achieve health-related goals but to remove particular people from society because of their political views or activities - and in a manner that did not appear to constitute imprisonment for political reasons.

In the last decade of the $20^{\text {th }}$ century some doctors were reported to be still failing to provide proper ethical care and accurate documentation of injuries suffered by prisoners though the issue of medical participation in human rights violations returned once more as a major ethical issue following the transfer of untried detainees to Guantanamo naval base in Cuba as part of the United States (US) response to the attacks on New York and Washington DC (commonly known as "9/11"). As of February 2018, 41 prisoners are still held there, all of them have been imprisoned for more than 10 years without recourse to fair trial and the standard of legal rights guaranteed under the US Constitution and national law.

Guantanamo has been described as a "legal black hole" 8 and "increasingly... a medical ethicsfree zone" 9 . These concerns revolve around the lack of legal due process available to detainees and coercive medical practices such as force feeding prisoners on hunger strike ${ }^{10}$. Voices within the medical profession have criticised the medical role in US practices ${ }^{11}$ and the inadequate ethical guidance elaborated by the US Department of Defence ${ }^{12}$. United Nations (UN) human rights officials have criticised practices at Guantanamo including the failure of the authorities to adequately protect the prisoners' right to health by over-riding their lack of consent to feeding ${ }^{13}$.

The report by the US Senate on the use of torture of security prisoners ${ }^{14}$ made clear that doctors were involved in the "enhanced interrogation" program of the Central Intelligence Agency ( $\mathrm{CIA})$. In a letter to a US Assistant Attorney General a ClA staff member wrote that an interrogation session would be stopped if, in the judgement of the interrogators or medical personnel, medical attention was required ${ }^{15}$. The report noted immediately below this passage that multiple CIA detainees were [nevertheless] subjected to the CIA's enhanced interrogation techniques despite their medical conditions ${ }^{15}$ but it doesn't state if this was done against medical advice or with the approval of the Agency doctors.

\section{Doctors and cruel punishments}

Doctors have historically been bystanders and gatekeepers in the carrying out of cruel punishments such as flogging, judicial amputation and executions. International medical ethics oppose a medical role in these punishments. While such state punishments have traditionally involved health professionals at least in activities such as certifying that the prisoner is fit for the punishment, medicating the prisoner, and (in the case of flogging) intervening to stop or suspend the punishment, since the 1970s both UN and standards for medical professionals have proscribed their participation in such punishments.

For example, the UN Principles of Medical Ethics relevant to the Role of Health Personnel, particularly Physicians, in the Protection of Prisoners and Detainees against Torture and 
Other Cruel, Inhuman or Degrading Treatment or Punishment opposes any medical role in torture or punishment. According to the Principles It is a contravention of medical ethics for health personnel, particularly physicians, to be involved in any professional relationship with prisoners or detainees the purpose of which is not solely to evaluate, protect or improve their physical and mental health ${ }^{16}$ (Principle 3 ). It also regards participation in torture or its facilitation as unethical (Principle 4).

The World Medical Association (WMA) has made several pronouncements on corporal and capital punishments, triggered by the introduction and apparently imminent use of execution by injection of toxic fluids in the United States when lethal injection (LI) execution was made legal in 1977. Plans to conduct the first such execution did not come to pass, and the first realistic probability of such execution was only reported four years after the adoption of such laws in several states.

Thomas "Sonny" Hayes, a black man, in Oklahoma - was scheduled for execution on 9 September 1981. After a court-ordered stay, it was rescheduled for 14 September. The Secretary General of the World WMA, Dr André Wynen, issued a statement opposing medical participation in LI executions. His statement was subsequently incorporated into a WMA resolution against medical participation in executions. It noted that Acting as an executioner is not the practice of medicine, and physician services are not required to carry out capital punishment. The following year, another black man, Charles Brooks Jr., became the first prisoner to be executed by lethal injection in Texas - in the presence of two physicians who monitored the process and advised the executioner ${ }^{17}$.

Since then lethal injection has been adopted by China, Taiwan, Guatemala, Philippines and Vietnam. Guatemala placed a moratorium on the death penalty in 2005 following a bungled first experience ${ }^{18}$; Philippines ended the use of $\mathrm{LI}$ when the death penalty was abolished by a constitutional change; Taiwan can carry out executions by gunshot or by lethal injection but, in practice, all executions are carried out by gunshot and China is an enthusiastic executing state, though the balance between executions by shooting and lethal injection is (like most other aspects of the death penalty in China) a secret. Vietnam retains shooting as the main execution method but has executed a small number of men by LI. However, as it happens in some states in the US, Vietnam is having difficulty finding a supplier of lethal substances for injection. This may be a determining factor in the use of particular methodologies ${ }^{19}$.

\section{Unethical practices against security prisoners}

Notwithstanding the wide range of medical ethics standards in place, physicians (and other health professionals) are still involved in wrongdoings. Even with clear guidelines against force-feeding, health care staff have supervised or participated in such practices, for example, with prisoners at Guantanamo. Force-feeding at Guantanamo has also been condemned by five UN Special Rapporteurs ${ }^{9}$ as well as numerous human rights organisations ${ }^{20}$. In October 2014, a US Court has ordered the release of 28 videos showing forcefeeding procedures. However, on 2 December 2014, lawyers for the US Justice Department filed a notice of appeal against the October court order requiring the release of the tapes ${ }^{21}$. At the time of writing the tapes remain subject to the appeal process.

In this same prison there was mass administration of the antimalarial mefloquine to detainees upon their arrival at Guantanamo. Cuba is a malaria-free island. While mefloquine has a role in the prevention of malaria, its use in Guantanamo was not consistent with recommended practice and it has been suggested that it may have been used because of its known adverse effects on the central nervous system, including hallucinations, depression and suicidal behaviour ${ }^{22}$. The true reason for the mass medication has not been documented but the institutionalised abusive treatment meted out to prisoners means that allegations of non-medical reasons for the use of such medication cannot simply be dismissed.

Over the past decade, psychologists in the US have been accused of participating in torture against foreign prisoners. In his 2014 book James Risen ${ }^{23}$ details evidence that the American Psychological Association worked directly and secretly with US government officials, including from the $\mathrm{CIA}$ and the White House, on its ethics policy. According to Risen, this collusion appeared to be aimed at ethically justifying involvement of psychologists in interrogations and ensuring psychologist's assistance in implementing and legitimising the Bush-era torture program. Human rights organizations have criticised the role of psychologists in the war on terror and have called for an investigation into 
that role and that of the American Psychological Association (APA) ${ }^{24}$. Some psychologists have been actively engaged in trying to expose the role of individual psychologists and the professional body in US practices in Guantanamo ${ }^{25,26}$.

\section{Where are we still failing?}

In day-to-day life in many regions, violence and human rights abuses are perpetrated against women, lesbian, gay, bisexual and transgender persons, black and ethnic minorities, people with disabilities, religious minorities and sex workers ${ }^{27}$.

Health professionals may also be witnesses to and even participate in abuses in situations depicted below. All these abuses are incompatible with professional ethics and with international law or, in some cases, reflect community values that are at odds with trends in human rights law. It is clear that health professionals must provide care in an ethical and confidential manner in cases of abuse but, as with torture, should not remain silent or passive. Among these situations:

\section{Violence against women}

García-Moreno and collaborators ${ }^{28}$ summarise threats to women and girls as comprising intimate partner violence and other violence, child sexual abuse, trafficking, genital mutilation, forced and early marriage and killings in the name of "honour". According to Devries and collaborators ${ }^{29}$ at least one in seven homicides globally and more than a one third of female homicides are perpetrated by an intimate partner, commonly representing the culmination of a long history of abuse.

The requirement of confidentiality should not be lightly laid aside and this is at the core of the debate about making mandatory the reporting of domestic or gender-based violence. World Health Organization (WHO) guidelines on responding to intimate partner violence included a recommendation against mandatory reporting by the health care provider to the police on the grounds that the possible benefits of mandatory reporting did not outweigh impingement of the woman's autonomy and decision making ${ }^{30}$. The WHO rated this as a "strong" recommendation but noted that it was based on very low-quality evidence. Nevertheless, reporting of intimate partner violence to criminal justice authorities by clinicians is mandatory in some countries and some US states ${ }^{31}$.

\section{Sexual minorities}

Even with the widespread recognition of the human rights of lesbians, gay, bisexual and transgender people 2778 countries of which around half are in Africa (in 37 out of 54 countries) currently make same-sex relationships illegal. Homosexual activity can be punished by death in five countries with two further countries possibly applying the death penalty within parts of their territory; the use of the death penalty is uncertain in four further countries $^{32}$. Moreover, social discrimination can lead to high levels of hate crime and violence against such citizens ${ }^{33}$.

\section{Migrants}

Notwithstanding human rights standards such as the 2003 Convention on the Rights of Migrant Workers $^{34}$ and the 1951 Convention and 1967 Protocol relating to the Status of Refugees ${ }^{35}$, there are proposals to change immigration policies in Europe, with both politicians and members of the public arguing that immigrants are coming to exploit the social security benefits and to "steal" jobs.

In the United Kingdom (UK), there are complaints that visitors are arriving for the purposes of health tourism to obtain free treatment from the British National Health Service. Xenophobia is widely seen in Europe and appears to be contributing to the rise of anti-immigrant political movements.

\section{Religious minorities}

Prejudice against Jews continues to be of concern throughout Europe ${ }^{36}$; some of this is attributed to growing opposition to the policies of the Israeli government towards the Palestinian peoples but most appears to result from anti-Semitism. Prejudice against Muslim minorities is also on the increase in Europe ${ }^{37}$ and elsewhere. Significantly, there is sectarian conflict among Muslims. In addition, Christians are at risk in a number of countries particularly in the Middle East ${ }^{38}$.

\section{Ethnic minorities}

While ethnic minorities can be found disproportionately in the most economically and socially deprived parts of society, their overrepresentation in prisons is a dramatic visual reminder of this fact. In the US, African-Americans comprise about $13 \%$ of the population, but account for $37 \%$ of those imprisoned ${ }^{39}$; life expectancy for African Americans is 3.5 years less than for white Americans ${ }^{40} .65 \%$ of prisoners in Brazil are black 
or mulattoes (compared to $51 \%$ of population which includes $7.6 \%$ black); $60 \%$ have not finished elementary school and $95 \%$ are poor or very poor ${ }^{41}$.

In Australia, Indigenous Australians are 15 times more likely to be imprisoned than nonIndigenous Australians and are almost twice as likely as non-Indigenous Australians to have reported being victim of physical or threatened violence. Indigenous women are "hospitalised for family violence-related assault at 31 times the rate of non-Indigenous women" ${ }^{42}$. Life expectancy for Indigenous Australians born in 2010-12 was estimated to be 10 years less than for non-Indigenous Australians ${ }^{43}$. These findings reflect a complex mix of historical deprivation, poverty, marginalisation and lack of effective service provision but can also reflect ingrained racist values.

It may be hard to keep campaigning for rights and justice when often we seem to go at best two steps forward and at worst one step forward and then two back. However, we must continue to work for justice and disrupt the status quo of violence and disparity - injustice is not immutable or inevitable. On the bright side, even with all the violence we have been seeing throughout the world against many different groups of individuals, the situation is improved compared to, say, 70 to 100 years ago. There were many positive developments to counteract the aforementioned violations. These include the spread of democratic values; the growth of the human rights movement which has flourished worldwide; the widespread adoption of standards against a range of human rights violations including the participation of medical doctors in facilitating torture but also in assisting in the death penalty.

Laws have been formulated and international declarations have been adopted to reduce the prevalence of human rights violations as the following section show.

\section{The Regulatory framework}

\section{United Nations}

- UN Universal Declaration of Human Rights (UDHR), Paris - 10 Dec 1948. This milestone document was drafted by representatives with different legal and cultural backgrounds from all regions of the world ${ }^{44}$ and adopted by the UN General Assembly in Paris on 10 December 1948;

- Human rights covenants, 1966: The International Covenant on Economic, Social and Cultural Rights and the International Covenant on Civil and Political Rights ${ }^{45}$ were adopted by the UN General Assembly on 16 December 1966, and gave legal force to the UDHR;

- Principles of Medical Ethics relevant to the Role of Health Personnel, particularly Physicians, in the Protection of Prisoners and Detainees against Torture and Other Cruel, Inhuman or Degrading Treatment or Punishment ${ }^{46}, 1982$.

The Code was introduced in the period during discussion of the Convention against Torture and it spells out the ethics of the relationship between health personnel, particularly physicians, and prisoners/ detainees ${ }^{46}$.

- International Ethical Guidelines for Healthrelated Research Involving Humans - Prepared by the Council for International Organisations of Medical Sciences (CIOMS) in collaboration with the World Health Organisation (WHO) ${ }^{47}$.

\section{World Medical Association}

The World Medical Association (WMA), the umbrella group for national medical associations, has adopted a number of statements against medical participation in human rights abuses. Despite having no formal international binding authority, the Association's ethics statements represent a consensus view of ethics values by the organized profession. While it is a fact that the WMA is the only supra-national medical body speaking on medical ethics and has been credited with producing influential statements to guide physicians, some commentators have voiced that WMA statements should not be regarded as universally binding. With respect to ethics and international humanitarian law see Sigrid Mehring's discussion of the Declaration of Geneva, the WMA International Code of Medical Ethics and the WMA Regulations in Times of Armed Conflict and other Situations of Violence ${ }^{48}$. She asserts that the WMA lacks the legitimacy to claim support from all doctors for these particular ethics principles. This scepticism does not seem to happen in other areas of ethics (the Declaration of Tokyo against medical involvement in torture, for example):

\section{WMA Declaration of Tokyo}

In 1975 in the wake of numerous reports of medical participation in torture in Latin America, the WMA adopted a short and very clear statement holding that physicians should not countenance, condone or participate in the practice of torture ${ }^{49}$. 


\section{Declaration of Hamburg}

In 1997, the WMA adopted this statement of support for medical doctors refusing to participate in...the use of torture... supporting these professionals that refuse to be a party to the use of torture ${ }^{50}$.

\section{Resolution on documentation of torture}

In 2003 the WMA resolved to emphasise the responsibility of physicians in the documentation and denunciation of acts of torture ${ }^{51}$.

\section{WMA Resolution on Physician Participation in Capital Punishment}

This statement adopted in 1981 was prompted by the imminent use of lethal injection executions. It was revised and amended in 2000 and opposes medical participation in any aspect of the death penalty ${ }^{52}$.

\section{WMA Declaration of Malta on Hunger Strikers, 1991}

It states that force feeding is never ethically acceptable. Even if intended to benefit, feeding accompanied by threats, coercion, force or use of physical restraints is a form of inhuman and degrading treatment ${ }^{53}$. This declaration has been widely cited in discussions on force feeding in Guantanamo and elsewhere.

Also in relation to research involving humans, there have been some gains since 1945:

- Nüremberg Code $1947^{54}$ - This ten points code arising from the Trial of Nazi physicians in Nuremberg underscored the need for researchers to respect the human subject autonomy and to obtain free and informed consent;

- Belmont Report 1979 - The National Commission for the Protection of Human Subjects of Biomedical and Behavioural Research was established by law to identify the basic ethical principles that should underlie the conduct of biomedical and behavioural research involving human subjects and to develop guidelines ${ }^{55}$. The resulting report focused on three principles: respect for persons, beneficence, and justice;

- WMA Declaration of Helsinki $1964^{49}$ - this established ethical standards guiding research involving human subjects. It has been revised many times, most recently in 2013 , and is widely referred to;

- Unesco Universal Declaration on Bioethics and Human Rights, 2005. The Declaration addressed ethical issues related to medicine, life sciences and associated technologies ${ }^{56}$.

The net effect of all this activity is that we now have clear statements guiding professional behaviour in medical research, in professional relationships in clinical practice and in dealing with persons who have lost their liberty and who are carrying out protests that might be self-harming.

\section{Social determinants, power relations and emancipation}

These are crucial issues that can only be truly resolved with extensive social change and it must be emphasised that they are intertwined with the risks and actual breaches of the human rights of vulnerable individuals and populations.

Of course, disparity, discrimination, prejudice, violence, racism will not just disappear with the adoption of laws, covenants or guidelines. Justice may be achieved when individuals, communities and countries receive their fair share, emancipate themselves to fight for their rights. Thucydides, in his "History of the Peloponnesian war" ${ }^{57}$ suggested that justice would prevail when those who are not subjected to injustice are as indignant as those who are. We would argue that justice will only prevail when those affected by injustice emancipate themselves by fighting for their rights.

To face disparity, exploitation, poverty and the melting pot for other described aggressions, there is no place for the so-called empowerment. Empowerment is repeated ad nauseam as a way to "give" capacity to individuals in relation to their needs and expectations - unfortunately empowerment is another figure of rhetoric as power is never given and very seldom shared. It usually means a top-down way of marginally providing a little to those in need, to pacify their claims.

Vulnerable individuals/countries will praise the "donors" for helping get what is nothing more than their rights, and this only perpetuates dependency, in a new sort of colonialism: give the rings, save the fingers and maintain the status quo of disparity and violence.

What is needed is emancipation, as proposed by Brazilian educator Paulo Freire ${ }^{58}$ : for this author human liberation will not occur accidentally, as a concession, but it will be a conquest of human praxis, demanding constant struggle to achieve it - there will be a moment when the oppressed take the initiative to fight and emancipate themselves from the oppressors. 
From disempowerment to emancipation: an action agenda

There are many possible ways to confront the challenges described above. To fight back we must exercise "constant vigilance and apprehension" and make visible all forms of violence, discrimination and prejudice against anyone and hold those responsible to account. Some believe it may even be possible to forgive but no one should ever forget what has happened and still happens; and by not forgetting we may be able to emancipate ourselves and keep fighting for equality, justice and against any form of discrimination, prejudice and violence.

\section{Prevention and actions}

\section{Training}

Simply informing health personnel of their ethical duties is not a guarantee of ethical behaviour. But it is a minimum requirement. Ethics and human rights are usually given little weight during education and this shortfall needs to be addressed.

\section{Society wide initiatives: fighting stigma and discrimination}

As we suggest above stigma and discrimination are a basis for the erosion of human rights and for the institutionalization of abusive practices. Measures to educate the health sector and the wider public about difference and mutual respect are essential. Gender awareness and a wider understanding of disability, ethnicity, and sexual orientation are essential components to deal with the needs of patients and wider public health.

\section{Ethical accountability}

The past decade of extra-legal practices used in Guantanamo and the analysis of unethical behaviour by health professionals can be added to the abusive role of medicine in the ill-treatment of prisoners in Latin America, the Soviet Union, South Africa and elsewhere.

\section{Addressing poor practice}

In addition to these gross violations are the examples of poor clinical or research practices that also have violated people's rights. All these cases have been marked by a singular lack of accountability in government, in ministries and among health professionals.
It should be noted that there are guidelines and codes already issued addressing this matter. As examples, the Brazilian Code of Medical Ethics ${ }^{59}$ (Chapter IV- On Human Rights) clearly states in its article 25 that doctors are forbidden to participate or be accomplice in and/or not to denounce the practice of torture, or other inhuman, cruel or degrading procedures; and to provide means, instruments, substances or knowledge that could facilitate these practices.

In the same line, the American Medical Association has stated, in light of the already mentioned US Senate report on interrogations that this could be a good time for physicians to make sure they understand their ethical obligations regarding torture and interrogation. AMA's Code of Medical Ethics gives specific directions regarding what physicians should and should not do in situations involving torture or coercive interrogation. With regard to torture, several key principles from AMA's Opinion E-2.067 must be observed:

- Physicians must oppose and must not participate in torture for any reason. Participation in torture includes, but is not limited to, providing or withholding any services, substances or knowledge to facilitate the practice of torture. Physicians must not be present when torture is used or threatened.

- Physicians should only treat individuals when it is in the patient's interest, not to verify health so that torture can begin or continue.

- Physicians should help provide support for victims of torture and whenever possible strive to change situations in which torture is practised or the potential for torture is great.

- This Opinion also notes that physicians who follow their calling as healers in treating torture victims should not be persecuted ${ }^{60}$.

This is followed by AMA's Opinion E-2.068 "Physicians have five ethical obligations concerning this subject:

- Physicians should only perform physical and mental assessments of detainees: to determine the need for and to provide medical care. When doing so, physicians must disclose the extent to which others have access to information included in medical records. Treatment must never be conditional on a patient's participation in an interrogation;

- Physicians must neither conduct nor directly participate in an interrogation: Being involved in interrogation undermines the physician's role as 
healer and thereby erodes trust in the individual physician and in the medical profession;

- Physicians must not monitor interrogations: with the intention of intervening in the process. This constitutes direct participation in interrogation;

- Physicians should not participate in developing effective interrogation strategies: except for general training purposes. These strategies must not threaten or cause physical injury or mental suffering and must be humane and respect the rights of individuals;

- Physicians must report their observations to the appropriate authorities: if they have reason to believe that interrogations are coercive. If those authorities are aware of coercive interrogations but have not intervened, physicians are ethically obligated to report the offences to independent authorities that have the power to investigate or adjudicate such allegations ${ }^{60}$.

\section{Avoiding institutionalisation of health care providers}

It is commonly seen that those who work in the same (or the same type of) institution over long periods adapt to the ruling ethos and lose a sharp critical vision. There must be a mechanism for changing the working environment of those working either with prisoners and detainees or with those who are held in social or health care institutions.

\section{Protecting whistle blowers}

The recent examples of Julian Assange and Edward Snowden (responsible respectively for the WikiLeaks website ${ }^{61}$ and for the leaks of documents from the US National Security Agency ${ }^{62}$ ) and many other less visible whistle blowers reveals that they are more likely to be attacked by those in power than thanked for revealing unacceptable or illegal behaviour. It must be pointed out that whistle-blowing and breaching national security are not fixed concepts since confidentiality and security are not absolute. Some government secrets may cover up illegality (thus offering a persuasive case for publication in the public interest) while others may not be based on illegal action but rather are a matter of judgement as to what is in the public interest. Moreover, whistleblowers may suffer negative reactions from colleagues (particularly where they are implicated in wrongdoing or are publicly embarrassed) and the public, despite acting in what they believe is the public interest. Whistle blowers can also face the same negative outcomes in the health sector.
To date, the limited support that they receive from enlightened observers are not matched by legal protection or strong encouragement from professional bodies. This must change.

\section{Justice}

Punish the real abusers: those with managerial responsibility for ill-treatment or unethical behaviour. International law provides a clear framework for holding abusers to account but justice must ordinarily be available within the victim's country.

\section{Compensate the victims}

Those who have suffered at the hands of the state, or have received inadequate protection of the state must be offered appropriate compensation. The UN Committee against Torture has provided a detailed commentary on how this might be approached ${ }^{63}$ but other forms of abuse also merit compensation for victims.

\section{Ensure that fair legal processes are in place}

The basic minimum requirements for a fair legal trial are set out in international and regional law $^{64}$. In addition, administrative law and medical ethics processes must meet adequate standards. These include compatibility with international law, transparency, access to legal assistance and right to appeal decisions.

In short, we underscore that the existing guidelines, declarations and codes must not only be put into practice but , most importantly, individuals and/or institutions accused of serious ethical failings should be held to account. For this end it will be necessary to establish independent mechanisms for investigation and to enforce necessary sanctions if the wrongdoings are confirmed. This is an opportunity for backing up the creation of a World Court of Human Rights ${ }^{65}$ under the jurisdiction of the United Nations.

\section{Emancipation}

Inculcate a sense of power in every citizen including among health professionals. This must be the power to act where human rights are at risk; where pressure is being brought to behave unethically; where clinical needs are being denied for non-clinical reasons. Both health professional and patient should be united in seeking to assert their rights to assure and to receive the care that is needed.

Thus, the term empowerment should be replaced by emancipation in the sense meant by 
Paulo Freire, who in his comprehensive work on education for freedom used the word in a broad sense of liberation and autonomy, exactly how it should be used when discussing citizenship, rights or combating disparities. In the same direction it should be applied in a global sense, that is, emancipation will not happen by chance, by concession, but it will be an achievement effected by human praxis, that demands uninterrupted fight: Liberation is thus similar to childbirth (...) The man who is thus born is a new man, viable only in the oppressor-oppressed contradiction and who overcomes this contradiction, achieving is superseded by the liberation of all men ${ }^{66}$.

\section{Final considerations}

There are still many problems related to the participation of the medical professionals in many situations that may or actually do breach human rights. On the other hand, there has been progress aiming at not only avoiding their participation in such practices but also to make them part of the solution. We have shown some of the possibilities for this change, which include the issuing of and the due respect to norms, declarations and laws and as important, the need for the dissemination of this discussion in diverse venues, especially with the real participation and emancipation of the affected and vulnerable populations.

Dirceu Greco, MD, PhD, is Professor Emeritus of the School of Medicine, Federal University of Minas Gerais, Belo Horizonte, Brazil. James Welsh, PhD is an independent researcher and this paper was written while he was a fellow at the London School of Hygiene and Tropical Medicine (LSHTM), University of London, London, United Kingdom.

\section{Referências}

1. Greco D, Welsh J. Human rights, ethics and the medical profession. Rev. bioét. (Impr.) [Internet]. 2016 [acesso 14 ago 2018];24(3):443-51. Disponível: https://bit.ly/2DZ28mJ

2. Arns PE. Brasil: nunca mais. Petropolis: Vozes; 1985.

3. Rivas FS. Traición a Hipócrates: médicos en el aparato represivo de la dictadura. Santiago de Chile: Cesoc; 1990.

4. Martirena G. Uruguay: la tortura y los médicos. Montevideo: Ediciones de la Banda Oriental; 1988.

5. British Medical Association. Medicine betrayed: the participation of doctors in human rights abuses. 2a ed. London: Zed Books; 1992.

6. Amnesty International. Greece: the first torturer's trial 1975 [Internet]. London: Amnesty International Publications; 1977 [acesso 10 jul 2016]. Disponível: https://bit.ly/2SiLIOZ

7. Bloch S, Reddaway P. Russia's political hospitals. London: Gollancz; 1977.

8. Steyn J. Guantanamo Bay: the legal black hole. Int Comp Law Q [Internet]. 2004 [acesso $11 \mathrm{dez}$ 2018];53(1):1-15. Disponível: https://bit.ly/2RPgD0q

9. Annas GJ, Crosby SS, Glantz LH. Guantanamo Bay: a medical ethics-free zone? N Engl J Med [Internet]. 2013 [acesso 11 dez 2018];369(2):101-3. Disponível: https://bit.ly/2MXQBqF

10. Annas GJ. Hunger strikes at Guantanamo: medical ethics and human rights in a "legal black hole". N Engl J Med [Internet]. 2006 [acesso 11 dez 2018];355(13):1377-82. Disponível: https://bit.ly/2WPmwyi

11. Lifton RJ. Doctors and torture. N Engl J Med [Internet]. 2004 [acesso 11 dez 2018];351(5):415-6. Disponível: https://bit.ly/2MUIWLb

12. Rubenstein L, Pross C, Davidoff F, lacopino V. Coercive US interrogation policies: a challenge to medical ethics. Jama [Internet]. 2005 [acesso $11 \mathrm{dez} 2018$ ];294(12):1544-9. Disponível: https://bit.ly/2RONYbM

13. Office of the United States High Commissioner for Human Rights. Press release [Internet]. 19 maio 2013 [acesso 24 ago 2016]. Disponível: https://bit.ly/2SvJxXR

14. United States. Senate Select Committee on Intelligence. Committee study of the Central Intelligence Agency's Detention and Interrogation Program [Internet]. 3 dez 2014 [acesso 2 jun 2015]. Disponível: https://bit.ly/2o2z7w6

15. United States. Op. cit. p. 420.

16. United Nations. General Assembly. Resolution UN no. 37/194. A/RES/37/19, de 18 de dezembro de 1982. Principles of medical ethics [Internet]. 18 dez 1982 [acesso 2 jun 2015]. Disponível: https://bit.ly/1lmUtxT

17. Amnesty International. Lethal injection: the medical technology of execution. Al Index: ACT 50/01/98 [Internet]. jan 1998 [acesso 11 dez 2018]. Disponível: https://bit.ly/2DI8ADm

18. Amnesty International. Execution by lethal injection: a quarter century of state poisoning. Al Index: ACT 50/007/2007 [Internet]. out 2007 [acesso 11 dez 2018]. Disponível: https://bit.ly/2UNOfiP

19. Barrell R. Utah set to reinstate firing squad executions amid lethal injection drug shortage. Huffington Post [Internet]. 23 mar 2015 [acesso $11 \mathrm{dez}$ 2018]. Disponível: https://bit.ly/2RPinH0

20. Human Rights Watch. Joint letter to Chuck Hagel [Secretary, Department of Defense] on the forcefeeding of hunger-striking prisoners at Guantánamo Bay [Internet]. 13 maio 2013 [acesso $11 \mathrm{dez}$ 2018]. Disponível: https://bit.ly/2SptHhT 
21. The Editorial Board. Release the Guantánamo force-feeding videos. The New York Times [Internet]. Editorial; 7 dez 2014 [acesso 2 jun 2015]. Disponível: https://nyti.ms/2WOb59Y

22. Nevin RL. Mass administration of the antimalarial drug mefloquine to Guantánamo detainees: a critical analysis. Trop Med Int Health [Internet]. 2012 [acesso 11 dez 2018];17(10):1281-8. Disponível: https://bit.ly/2Bvud3E

23. Risen J. Pay any price: greed, power, and endless war. Boston: Houghton Mifflin Harcourt; 2014.

24. PHR calls for federal probe into American Psychological Association's role in CIA torture program. Physicians for Human Rights [Internet]. Resources; 16 out 2014 [acesso 11 dez 2018]. Disponível: https://bit.ly/2GI7coc

25. Coalition for an ethical psychology: human rights, ethics, social justice. Ethical Psychology [Internet]. 18 fev 2013 [acesso 20 out 2015]. Disponível: https://bit.ly/2WTUfqa

26. Malin AJ. Psychologists at Guantanamo Bay: can their ethical violations be justified? JEMH [Internet]. 2012 [acesso 11 Dec 2018];(7):1-5. Disponível: https://bit.ly/2MYhtXH

27. United Nations. General Assembly. A/HRC/19/41, de 17 de novembro de 2011. Discriminatory laws and practices and acts of violence against individuals based on their sexual orientation and gender identity [Internet]. 17 nov 2011 [acesso 4 mar 2016]. Disponível: https://bit.ly/2BuLzxr

28. García-Moreno C, Zimmerman C, Morris-Gehring A, Heise L, Amin A, Abrahams N et al. Addressing violence against women: a call to action. Lancet [Internet]. 2015 [acesso 29 nov 2018];385(9978):1685-95. Disponível: https://bit.ly/2N3Scvq

29. Devries KM, Mak JYT, García-Moreno C, Petzold M, Child JC, Falder G et al. The global prevalence of intimate partner violence against women. Science [Internet]. 2013 [acesso 29 nov 2018];340(6140):1527-8. Disponível: https://bit.ly/2GGp5ge

30. World Health Organization. Responding to intimate partner violence and sexual violence against women: WHO clinical and policy guidelines [Internet]. Geneva: WHO; 2013 [acesso 23 out 2014]. p. 41. Disponível: https://bit.ly/1wkpds6

31. Feder G, Wathen CN, MacMillan HL. An evidence-based response to intimate partner violence: WHO guidelines. Jama [Internet]. 2013 [acesso 23 out 2014];310(5):479-80. Disponível: https://bit.ly/2SKOqMA

32. Itaborahy LP, Zhu J. State-sponsored homophobia: a world survey of laws: criminalisation, protection and recognition of same-sex love [Internet]. Geneva: International Lesbian, Gay, Bisexual, Trans and Intersex Association; 2014 [acesso 4 jun 2015]. p. 16-8. Disponível: https://bit.ly/2thU3Uk

33. Amnesty International. Europe: because of who I am: homophobia, transphobia and hate crimes in Europe [Internet]. London: Amnesty International Publications; 2013 [acesso 14 ago 2018]. Disponível: https://bit.ly/2GkGvzl

34. United Nations Educational, Scientific and Cultural Organization. United Nations Convention on Migrants' Rights [Internet]. Paris: Unesco; 2005 [acesso 14 ago 2018]. Disponível: https://bit.ly/2Snowzf

35. United Nations. General Assembly. Convention relating to the status of refugees [Internet]. 28 jul 1951 [acesso 5 maio 2015]. Disponível: https://bit.ly/2GCrFUA

36. European Union Agency for Fundamental Rights. Discrimination and hate crime against Jews in EU Member States: experiences and perceptions of antisemitism [Internet]. Vienna: FRA; 2013 [acesso 10 jun 2016]. Disponível: https://bit.ly/1hNLIAa

37. Amnesty International. Choice and prejudice: discrimination against Muslims in Europe [Internet]. London: Amnesty International Publications; 2012 [acesso 8 maio 2015]. Disponível: https://bit.ly/2GC4dXA

38. Human Rights Watch. Egypt: mass attacks on churches [Internet]. 21 ago 2013 [acesso 8 maio 2015]. Disponível: https://bit.ly/1BghpqL

39. Carson EA. Prisoners in 2013. BJS [Internet]. 2014 [acesso 8 maio 2015];NCJ 247282. Disponível: https://bit.ly/1uDNndG

40. Cunningham TH, Croft JB, Liu Y, Lu H, Eke PI, Giles WH. Vital signs: racial disparities in age-specific mortality among blacks or African Americans: United States, 1999-2015. MMWR Morb Mortal Wkly Rep [Internet]. 2017 [acesso 11 dez 2018];66(17):444-56. Disponível: https://bit.ly/2qJAdyC

41. Gomes LF. Perfil dos presos no Brasil em 2012. Jusbrasil [Internet]. 2013 [acesso 6 maio 2015]. Disponível: https://bit.ly/1QemCJI

42. Kidd J. Over-representation of Indigenous Australians in prison a catastrophe, says Mick Gooda, the Aboriginal and Torres Strait Islander Social Justice Commissioner. ABC News [Internet]. 5 dez 2014 [acesso 6 maio 2015]. Disponível: https://ab.co/2UQxPEs

43. Australian Government. Department of the Prime Minister and Cabinet. Aboriginal and Torres Strait Islander Health Performance Framework 2014 Report [Internet]. 2014 [acesso 11 dez 2018]. Disponível: https://bit.ly/2IILvoz

44. United Nations. Universal declaration of human rights [Internet]. 10 dez 1948 [acesso 22 maio 2015]. Disponível: https://bit.ly/108fonS

45. United Nations. Human Rights. Office of the High Commissioner. International Covenant on Economic, Social and Cultural Rights [Internet]. 16 dez 1966 [acesso 5 ago 2015]. Disponível: https://bit.ly/2MOWMwA

46. United Nations. Human Rights. Office of the High Commissioner. Principles of medical ethics relevant to the role of health personnel, particularly physicians, in the protection of prisoners and detainees against torture and other cruel, inhuman or degrading treatment or punishment [Internet]. 18 dez 1982 [acesso 5 ago 2015]. Disponível: https://bit.ly/2I1k30e 
47. Council for International Organizations of Medical Sciences, World Health Organization. International ethical guidelines for health-related research involving humans [Internet]. Geneva: Cioms; 2016 [acesso 4 mar 2017]. Disponível: https://bit.ly/2rzX9BO

48. Mehring S. First do no harm: medical ethics in international humanitarian law. Amsterdam: Brill; 2014.

49. World Medical Association. Declaration of Helsinki [Internet]. 2013 [acesso $11 \mathrm{dez} 2018$ ]. Disponível: https://bit.ly/2MYCb9W

50. World Medical Association. Declaration of Hamburg [Internet]. 2007 [acesso $11 \mathrm{dez} 2018$ ] Disponível: https://bit.ly/2SGexnR

51. World Medical Association. Resolution on the responsibility of physicians in the documentation and denunciation of acts of torture or cruel or inhuman or degrading treatment [Internet]. 2007 [acesso $10 \mathrm{dez}$ 2018]. Disponível: https://bit.ly/2N02Suz

52. World Medical Association. Resolution on physician participation in capital punishment [Internet]. 2008 [acesso 15 mar 2016]. Disponível: https://bit.ly/2GldXGA

53. World Medical Association. Declaration of Malta on hunger strikers [Internet]. 2006 [acesso 15 mar 2016]. Disponível: https://bit.ly/2oonPSu

54. US National Institute of Health. Trials of war criminals before the Nüremberg Military Tribunals [Internet]. Washington: US Government Printing Office; 1949 [acesso 14 jul 2015]. p. 181-2. Disponível: https://bit.ly/2tf610D

55. US National Commission for the Protection of Human Subjects of Biomedical and Behavioral Research. The Belmont report: ethical principles and guidelines for the protection of human subjects of research [Internet]. Bethesda: US Government Printing Office; 1979 [acesso 3 set 2015]. Disponível: https://bit.ly/1m4nLEE

56. United Nations Educational, Scientific and Cultural Organization. Universal declaration on bioethics and human rights [Internet]. 19 dez 2005 [acesso 3 mar 2016]. Disponível: https://bit.ly/1fIKY5G

57. Thucydides. History of the Peloponnesian war. Harmondsworth: Penguin; 1972.

58. Freire P. Pedagogy of the oppressed. London: Penguin; 1972.

59. Conselho Federal de Medicina. Código de Ética Médica: Resolução CFM no 1.931/09 [Internet]. Brasília: CFM; 2010 [acesso 29 nov 2018]. Disponível: https://bit.ly/2gyRqtD

60. American Medical Association. Torture, coercive interrogations and physicians [Internet]. 12 dez 2014 [acesso 3 out 2016]. Disponível: https://bit.ly/2WY1MnV

61. WikiLeaks [Internet]. [s.d.] [acesso 12 ago 2018]. Disponível: https://wikileaks.org/

62. The Guardian. The NSA files [Internet]. [s.d.] [acesso 12 ago 2018]. Disponível: https://bit.ly/2cmqvxE

63. United Nations. CAT/C/GC/3. Convention against Torture and Other Cruel, Inhuman or Degrading Treatment or Punishment: general comment no. 3 of the Committee against Torture [Internet]. 19 nov 2012 [acesso 5 ago 2015]. Disponível: https://bit.ly/1LjclAM

64. Amnesty International. Fair trial manual [Internet]. 2a ed. London: Amnesty International Publications; 2014 [acesso 3 mar 2016]. Disponível: https://bit.ly/1LEm8be

65. World Court of Human Rights Development Project [Internet]. [s.d.] [acesso 5 ago 2015]. Disponivel: https://bit.ly/2GCxvFA

66. Freire P. Pedagogia dos sonhos possíveis. São Paulo: Unesp; 2001.

\section{Participation of the authors}

The authors participated equally in the design, writing and revision of the text.

Correspondência

Dirceu Greco - Rua Goitacazes, 14 CEP 3190-050. Belo Horizonte/MG, Brasil

Dirceu Greco - MD - dirceugreco@gmail.com

(iD) $0000-0002-4419-5634$

James Welsh - PhD - jameskwelsh@netscape.net

(iD) $0000-0002-6045-4296$ 